\title{
Museum and Maps in Virtual Reality
}

\author{
Ivan Grinko \\ Laboratory for Museum Design and Planning \\ 2 Kosmonavtov Street, Moscow 129366 \\ Russian Federation \\ wagr-j@inbox.ru
}

\section{INTRODUCTION}

According new trends, more and more museums have started using permanent expositions with computers, monitors and touch-screens. But development of rapidly advancing technology has often out-stripped conceptual museum proposals and now very often museums are faced with a deficit of high-quality multimedia content.

One of the variants is an old instrument in museum practice - Maps. Museums and maps have many overlapping points, like instruments of identity, so it's role in museum space is more than logical. Benedict Andersen announced museums and maps as the two main instruments of nation building (Andersen, 2006).

\section{THE INFORMATIONAL POTENTIAL OF MAPS}

It was not an exaggeration, because these two define the most important categories for man - time and space. In spite everything, it is still so, but it is very interesting how these instruments conjoin and how museums can use maps for reaching their goals. Developing the informational potential of maps in creating multimedia content looks a very promising idea, because it helps create a truly new product.

Therefore it is high time to analyze previous experiences in this sphere and check out the most interesting cases. We will not consider cases when maps become museum objects just because of their aesthetics or historical value or that become an element of a museum's design. The main concepts are the following:

- Combination of historical spaces (Museum of Warsaw Uprising, Museum of Catalonian History)

- Visual classification (Museum Blau, Shanghai Museum)
- "Visualization of links" (Imperial War Museum, Chopin Museum)

- Edutainment (Cosmocaixa, Museum of the History of Polish Jews)

- Promotion (Rostov Museum, The Historical Museum of the City of Krakow)

The problem of combining history and contemporaneity concerns practically every museum and this can be solved by virtual mapping. The virtual map in the Museum of the History of Catalonia for example, combines two spaces of Barcelona: historical (The time of the Civil war 1936-1939) and contemporary. A visitor has possibility of seeing the location of airstrikes in the plan of the contemporary city and thus provokes much more emotions than a simple story about it. In the Museum of Warsaw Uprising, this method was developed and visitors can see a 3D-plan of the city that was totally destroyed during World War II. Both for Varsovians and tourists to the Polish capital, it is an important and emotive experience.

\section{MAPPING AS A UNIVERSAL BASIS FOR ANY KIND OF CLASSIFICATION}

However this combination of two spaces can create positive as well as negative emotions. In Shanghai Municipal History Museum, the whole history of the city was reconstructed in this way. A virtual map shows the real scale of events that changed a simple town into one of the biggest cities of the world.

Mapping is a universal basis for any kind of classification, especially when we deal with big data. For example, the Museum Blau (Barcelona) uses world maps to show the diversity of flowers and regions of their origin. In this case a visitor may not remember a lot of detailed information, but receives a strong association between, for example, a spice and its homeland. 
In the Latvian Military Museum (Riga), virtual mapping becomes a database about the army of an independent Latvia in the period between the two World Wars. On this map of Latvia you can find information including the ground location of all their military troops. Also this map includes plans of all towns, so a visitor can even find out the location of every barracks. It gives both opportunities for researchers in micro history, and a simple child who wishes to see where his grandfather served.

Virtual maps also become one of the best platforms for edutainment. Children enjoy maps because they make many abstract things real. We should not forget that any map by itself helps in the formation and development of spatial thinking. It is very useful in every program for children but the inclusion of a virtual map can double these effects.

In Cosmocaixa, Barcelona, virtual mapping is a framework for a difficult game that imitates a rescue operation in the Mediterranean Sea and includes plenty of changing information that is needed for successful final outcome. The Museum of Polish Jews (Warsaw), uses old maps to make a virtual game about medieval trade so children can learn geography and history through play. Using maps is always fascinating for children and the Estonian Maritime Museum makes clever use of this. A standard geographical map is projected onto a box filled with sand so that everyone can change the relief on the map, simply by moving the sand.

Returning to the theme of visualization, we should explore virtual mapping when we have to combine data of different kinds. The Museum of Chopin was faced with a difficult problem of how it should share their national symbol, Frederic Chopin with the whole country. Their answer was very innovative and impressive. The key element in the exposition was made as a virtual map of Poland on which visitors can find many un-obvious links between the life and music of Chopin and Polish Culture and History. Designers put together music, gravures, paintings, photographs and video to construct the centerpiece exhibit of the museum.

\section{CONCLUSION}

The visual power of maps today can greatly enhance any museum projects. The central exhibit in the exposition in the Rostov Museum is a film based on the special "Chronomap", combining the geography and history of the Rostov region. This impressive show creates absolutely new image of the museum and town and is also used by them as a promotional film.

Hence we can conclude that all the combinations of museums and maps described half a century ago are still very vital for museum practice and helping to solve conceptual problems in modern museum design and planning.

\section{REFERENCES}

Alpers S. (1987) The mapping impulse in the Dutch art. Art and Cartography: Six Historical Essays. Dir. David Woodward. Chicago, USA.

Andersen B. (1991) Imagined Communities: Reflections on the Origin and Spread of Nationalism. Verso.

Battersby S. \& Goldsberry K. (2010) Transition Behaviors in Dynamic Thematic Maps. Cartographic Perspectives, 65, 16-32.

Edensor T. (2002) National Identity, Popular Culture and Everyday Life. Berg. 